[Article]

\title{
两种疏水型膦类离子液体的密度、动力粘度及电导率
}

\author{
郑其格 ${ }^{1}$ 刘 惠 ${ }^{2,3}$ 夏 泉 ${ }^{1}$ 刘青山 ${ }^{1,4, *}$ 牟 林 $^{1, *}$ \\ ('沈阳农业大学理学院, 沈阳 110866; ${ }^{2}$ 上海环境卫生工程设计院, 上海 200232; \\ ${ }^{3}$ 上海污染场地修复工程技术研究中心, 上海 200232; ${ }^{4}$ 沈阳农业大学土地与环境学院, 沈阳 110866)
}

\begin{abstract}
摘要: 通过传统的方法, 制备了两种对水和空气稳定的四烷基膦类离子液体。离子液体是: 己基三丁基膦四 氟化嗍和已基三丁基膦双三氟甲基磺酸亚胺。在 $T=283.15-353.15 \mathrm{~K}$ 温度范围内, 测定了两个离子液体的 密度、动力粘度及电导率。讨论了温度、阴离子结构对离子液体的性质的影响。结合文献报道的其它离子液 体, 讨论了该类离子液体性质随阳离子结构的变化规律, 并与咪坐类离子液体的性质进行了比较。通过经验 方程, 利用密度数据计算了两个离子液体的重要热力学性质参数, 例如: 分子体积、标准摩尔熵及晶格能 等。并将估算性质与传统的咪坐、吡啶类离子液体进行了对比。通过密度和电导率确定了离子液体的摩尔电 导率。讨论了 Vogel-Fulcher-Tamman (VFT) 方程和Arrhenius 方程对于粘度和电导率拟合的可行性, 并估算 了电导活化能及流动活化能。通过Walden 规则, 描述了密度、粘度及电导率之间的联系。有关研究对新型 离子液体的合成及其工业化的应用具有十分重要意义。
\end{abstract}

关键词: 离子液体; 密度; 动力粘度; 电导率; Walden规则

中图分类号: 0642

\section{Density, Dynamic Viscosity and Electrical Conductivity of Two Hydrophobic Phosphonium Ionic Liquids}

\author{
ZHENG Qi-Ge $\quad$ LIU Hui ${ }^{2,3} \quad$ XIA Quan ${ }^{1} \quad$ LIU Qing-Shan ${ }^{1,4, *} \quad$ MOU Lin ${ }^{1, *}$ \\ ('School of Science, Shenyang Agricultural University, Shenyang 110866, P. R. China; \\ ${ }^{2}$ Shanghai Environmental Sanitation Engineering Design Institute, Shanghai 200232, P. R. China; \\ ${ }^{3}$ Shanghai Engineering Research Center of Contaminated Sites Remediation, Shanghai 200232, P. R. China; \\ ${ }^{4}$ College of Land and Environment, Shenyang Agricultural University, Shenyang 110866, P. R. China)
}

\begin{abstract}
Two air and water stable hydrophobic phosphonium ionic liquids (ILs), tributyl-hexylphosphonium tetrafluoroborate ([P4446] $\left[\mathrm{BF}_{4}\right]$ ) and tributyl-hexylphosphonium bis(trifluoromethylsulfonyl)imide ([P4446][NTf $]$ ), were prepared by the traditional method. Their basic physico-chemical properties of density, dynamic viscosity, and electrical conductivity were measured in the temperature range of $283.15-353.15 \mathrm{~K}$. The effect of the temperature and structure of the anion on the thermodynamic properties were discussed. The properties are compared with the cation structures changing of the phosphonium type ILs. The most important thermodynamic properties for their practical application, such as molecular volume, standard molar entropy, and lattice energy, were calculated from their density using empirical equations. The calculated values were compared with those of imdazolium and pyridinium type ILs. Molar electrical conductivity was determined from density and electrical conductivity. The applicability of the Vogel-Fulcher-Tamman (VFT) and Arrhenius equations to the fitting of the dynamic viscosity and electrical conductivity was validated. The activation of the electrical conductivity and
\end{abstract}

Received: November 10, 2016; Revised: December 29, 2016; Published online: December 29, 2016.

*Corresponding authors. LIU Qing-Shan, Email: liuqingshan@dicp.ac.cn; Tel: +86-13478787524. MOU Lin, Email: myname-mulin@tom.com; Tel: +86-13840537205.

The project was supported by the Program for Liaoning Excellent Talents in University, China (LJQ2015099).

辽宁省高等学校优秀人才支持计划(LJQ2015099)资助项目

(C) Editorial office of Acta Physico-Chimica Sinica 
dynamic viscosity were obtained from the final VFT equation. According to the Walden rule, the density, dynamic viscosity, and electrical conductivity were described by the Walden equation. The results are very important for academic studies as well as industrial applications of these ILs.

Key Words: Ionic liquids; Density; Dynamic viscosity; Electrical conductivity; Walden rule

\section{Introduction}

The use of ionic liquids (ILs) as green solvents has received much attention because of their physico-chemical properties ${ }^{1-4}$. ILs commonly exhibit low melting temperatures, good solvation, negligible vapor pressure, high electrical conductivity, good thermal stability, and good designability, among other factors.

As a recent example, tetra(alkyl) phosphonium ionic liquids (TAPILs), with a stable cation, have been synthesized and systematically applied to different areas. These TAPILs commonly exhibit low density, low electrical conductivity, high dynamic viscosity, high thermal stability, and high electrochemical stability $^{5,6}$. TAPILs with strong nucleophilic anions are significantly more stable than the analogous tetra-alkyl ammonium type ILs? Because of the high dynamic viscosity, TAPILs are also used as the stationary phases for gas chromatography ${ }^{8,9}$. Many TAPILs exhibite a unique phase behavior with water by increasing or decreasing the temperature, and the mixing of water and TAPILs shows the lowers critical solution temperature $(\mathrm{LCST})^{10-12}$. In addition to temperature, $\mathrm{CO}_{2}$ and $\mathrm{N}_{2}$ can also be used to reversibly change the phase from homogeneous to separated liquid-liquid ${ }^{13}$. TAPILs have also been used for the absorption of $\mathrm{CO}_{2}$ and $\mathrm{SO}_{2}$, where $\mathrm{CO}_{2}$ can be captured by tuning the basicity of the TAPIL ${ }^{14}$, and multiple-site absorption can be used for $\mathrm{SO}_{2}$ capture in the anion of several azole-based TAPILs ${ }^{15}$. Although such TAPILs have exhibited outstanding properties, the basis for these properties is relatively unknown, which has prohibited the synthesis and application of new TAPILs. The properties of trihexyl (tetradecyl)phosphonium type ILs have also been studied as examples of common TAPILs ${ }^{16-18}$. However, such cation TAPILs exhibit greater molecular volumes and higher dynamic viscosities than do more common ILs ${ }^{19-29}$.

Recently, Tsunashima et al. ${ }^{6}$ studied the physical and electrochemical properties of some quaternary phosphonium cation ILs with tetrafluoroborate and bis(trifluoromethylsulfonyl)imide anions included in this type of IL. These two types of anion IL include tributyl(octyl)phosphonium tetrafluoroborate ([P4448] $\left.\left[\mathrm{BF}_{4}\right]\right)$, tributyl(dodecyl)phosphonium tetrafluoroborate ([P444(12)] $\left.\left[\mathrm{BF}_{4}\right]\right)$, tributyl(octyl)phosphonium bis(trifluoromethylsulfonyl)imide ([P4448] [ $\left.\left.\mathrm{NTf}_{2}\right]\right)$, and tributyl(dodecyl)phosphonium bis(trifluoromethylsulfonyl)imide ([P444(12)] [NTf $]$ ). According to common experience, the influence of the alkyl chain length on the IL properties is clear. In this work, two TAPILs, $[\mathrm{P} 4446]\left[\mathrm{BF}_{4}\right]$ and $[\mathrm{P} 4446]\left[\mathrm{NTf}_{2}\right]$, were prepared for study by an ion exchange method to further understand this type of TAPIL. The two TAPILs have lower molecular volumes and lower dynamic viscosities relative to trihexyl(tetradecyl)phosphonium type
ILs. The density, dynamic viscosity, and electrical conductivity were probed over the temperature range from $(283.15 \pm 0.05)$ to $(353.15 \pm 0.05) \mathrm{K}$. The influences of the anion and of methylene introduction on the properties are discussed. Other IL properties are also predicted based on empirical values from previous experiment. These predicted values include density, standard molar entropy, and lattice energy. The values are also compared with literature values ${ }^{6}$. The work provides information on the influence of the anion to the properties after probing of the basic properties of these systems.

\section{Experimental}

\subsection{Materials}

Ethyl acetate (Beijing Yili Chemical Reagent Co., China), acetonitrile (Tianjin Tianhe Chemical Reagent Co., China), sodium tetrafluoroborate $\left(\mathrm{NaBF}_{4}\right)$ (Shanghai Zhuorui Chemical Co., China), bis(trifluoromethylsulfonyl)imide lithium salt ( $\left.\operatorname{LiNTf}_{2}\right)$ (Rhodia Co., China), 1-bromohexane (Beijing Yili Chemical Reagent Co., China), and tri- $n$-butylphosphine (Shandong Weitian Chemical Reagent Co., China) were used in the synthesis process. All provenance and mass fraction purities of the used materials are listed in Table 1.

\subsection{Preparation of TAPILs $[\mathrm{P} 4446]\left[\mathrm{BF}_{4}\right]$ and [P4446][NTf ${ }_{2}$ ]}

TAPILs [P4446] $\left[\mathrm{BF}_{4}\right]$ and $[\mathrm{P} 4446]\left[\mathrm{NTf}_{2}\right]$ were synthesized by methods described elsewhere ${ }^{30,31}$. Tributyl(hexyl)phosphonium bromide ([P4446][Br] ) was first synthesized. A slight excess of 1bromohexane was added dropwise into tributylphosphine with stirring at $353 \mathrm{~K}$ for $24 \mathrm{~h}$. The white product, [P4446][Br], was recrystallized from an ethyl acetate and acetonitrile solution (the ratio of the volume being $1: 1)$ several times. The white product was dried in high vacuum for $48 \mathrm{~h}$ at $353 \mathrm{~K}$ before the final product synthesis was carried out.

The hydrophobic TAPILs [P4446] [BF $]$ and [P4446] [NTf 2$]$ were synthesized by ion exchange in a distilled water/dichloromethane system. The white product $[\mathrm{P} 4446][\mathrm{Br}]$ was placed in a

Table 1 Provenance and mass fraction purity of the used materials

\begin{tabular}{cccc}
\hline Chemical name & Provenance & CAS No. & Purity \\
\hline ethyl acetate & Beijing Yili & $141-78-6$ & $>0.99$ \\
acetonitrile & Tianjin Tianhe & $75-05-8$ & $>0.99$ \\
NaBF $_{4}$ & Shanghai Zhuorui & $13755-29-8$ & $>0.99$ \\
LiNTf $_{2}$ & Rhodia (Franch) & $90076-65-6$ & $>0.99$ \\
1-bromohexane & Beijing Yili & $111-25-1$ & $>0.99$ \\
tri- $n$-butylphosphine & Shandong Weitian & $998-40-3$ & $>0.98$ \\
\hline
\end{tabular}


flask and dissolved with the distilled water/dichloromethane system. An equivalent amount of $\mathrm{NaBF}_{4}$ or $\mathrm{LiNTf}_{2}$ salt, for $[\mathrm{P} 4446]\left[\mathrm{BF}_{4}\right]$ or [P4446] $\left[\mathrm{NTf}_{2}\right]$, respectively, was added into the system with stirring. The TAPIL and dichloromethane phase was washed with distilled water until no $\mathrm{Br}^{-}$was present, where the presence was checked using an $\mathrm{AgNO}_{3} / \mathrm{HNO}_{3}$ solution. The colorless liquid was obtained and dried ( $353 \mathrm{~K}$ for $48 \mathrm{~h}$ ) under vacuum after washing. The final product TAPILs were characterized by ${ }^{1} \mathrm{H}$ NMR spectroscopy. The final mass fraction purities of the TAPILs were estimated from ${ }^{1} \mathrm{H}$ NMR spectra to be better than $99 \%$ (see Figs.S1 and S2 in the Supporting Information). The structures of TAPILs [P4446] $\left[\mathrm{BF}_{4}\right]$ and $[\mathrm{P} 4446]\left[\mathrm{NTf}_{2}\right]$ are presented in Scheme 1.

\subsection{Water content}

The water content of the TAPILs [P4446] $\left[\mathrm{BF}_{4}\right]$ and [P4446] $\left[\mathrm{NTf}_{2}\right]$ was determined by a Cou-Lo Aquamax Karl Fischer Moisture Meter (v.10.06). The water contents of the samples is less than $300 \times 10^{-6}$ (mass fraction) before and after determination of the system properties.

\subsection{Density and dynamic viscosity}

An Anton Paar SVM3000 (Anton Paar Shanghai Trading Co. Ltd.) was used for determining the density and dynamic viscosity of the TAPILs [P4446] $\left[\mathrm{BF}_{4}\right]$ and $[\mathrm{P} 4446]\left[\mathrm{NTf}_{2}\right]$. The temperature range of the measurement is from $(283.15 \pm 0.05)$ to $(353.15 \pm$ $0.05) \mathrm{K}$ per $5 \mathrm{~K}$, and thermal equilibrium was obtained in $30 \mathrm{~min}$. The experimental error was estimated as $\pm 0.0002 \mathrm{~g} \cdot \mathrm{cm}^{-3}$ for the density and the uncertainty was estimated to be $\pm 1 \%$ for the dynamic viscosity.

\subsection{Electrical conductivity}

The electrical conductivities of the TAPILs $[\mathrm{P} 4446]\left[\mathrm{BF}_{4}\right]$ and [P4446] $\left[\mathrm{NTf}_{2}\right]$ were recorded using a MP522 conductivity meter (San Xin Electronic Co.) with a $1 \mathrm{~cm}^{-1}$ cell constant. The cell was calibrated using a standard aqueous $\mathrm{KCl}$ solution. The data were recorded every $5 \mathrm{~K}$ once thermal equilibrium was attained after $30 \mathrm{~min}$ from the temperature increase of $(283.15 \pm 0.05)$ to $(353.15 \pm 0.05) \mathrm{K}$. The uncertainty is estimated to be $\pm 1 \%$.

The values of density, dynamic viscosity, and electrical conductivity are listed in Tables 2 and 3.

\section{Results and discussion}

From Tables 2 and 3, the density and dynamic viscosity can be seen to decrease with an increase temperature, and the electrical conductivity contrasts with the above two properties, where the data significantly increases in value with an increase temperature.

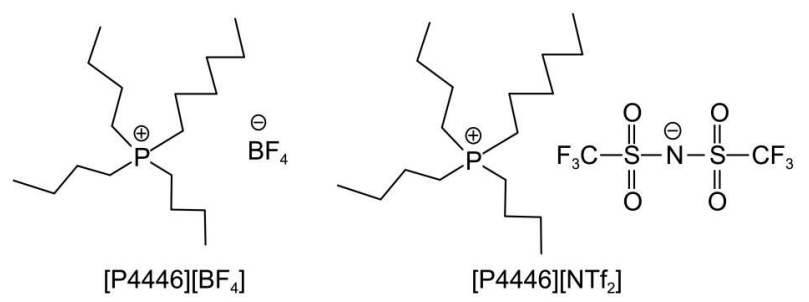

Scheme 1 Structures of TAPILs $[\mathrm{P} 4446]_{\left[\mathrm{BF}_{4}\right]}$ and $[\mathrm{P4446}]\left[\mathrm{NTf}_{2}\right]$
Table 2 Experimental values of density, $\rho$, dynamic viscosity, $\eta$, and electrical conductivity, $\sigma$, of $\left[\mathrm{P4446}_{[}\left[\mathrm{BF}_{4}\right]\right.$ from 283.15 to 353.15 $\mathrm{K}$ at pressure $\boldsymbol{p}=0.1 \mathrm{MPa}$

\begin{tabular}{cccc}
\hline$T / \mathrm{K}$ & $\rho /\left(\mathrm{g} \cdot \mathrm{cm}^{-3}\right)$ & $\eta /(\mathrm{mPa} \cdot \mathrm{s})$ & $\sigma /\left(\mathrm{mS} \cdot \mathrm{cm}^{-1}\right)$ \\
\hline 283.15 & 1.0130 & 4909.7 & 0.0297 \\
288.15 & 1.0099 & 3153.5 & 0.0428 \\
293.15 & 1.0067 & 2088.2 & 0.0639 \\
298.15 & 1.0036 & 1415.2 & 0.0904 \\
303.15 & 1.0005 & 982.12 & 0.1259 \\
308.15 & 0.9974 & 696.55 & 0.1713 \\
313.15 & 0.9946 & 504.02 & 0.2330 \\
318.15 & 0.9915 & 371.46 & 0.3090 \\
323.15 & 0.9884 & 278.52 & 0.4030 \\
328.15 & 0.9854 & 212.04 & 0.5190 \\
333.15 & 0.9824 & 163.86 & 0.6530 \\
338.15 & 0.9794 & 128.36 & 0.8280 \\
343.15 & 0.9764 & 101.84 & 1.0280 \\
348.15 & 0.9735 & 81.776 & 1.2650 \\
353.15 & 0.9705 & 66.434 & 1.5500 \\
\hline
\end{tabular}

$\rho$ : density; $\eta$ : dynamic viscosity; $\sigma$ : electrical conductivity. The uncertainty is $\pm 0.0002 \mathrm{~g} \cdot \mathrm{cm}^{-3}$ for density. The uncertainties are $\pm 1 \%$ for electrical conductivity and dynamic viscosity. The uncertainty is $\pm 0.05 \mathrm{~K}$ for temperature.

Table 3 Experimental values of density, $\rho$, dynamic viscosity, $\eta$, and electrical conductivity, $\sigma$, of $[\mathrm{P4446}]\left[\mathrm{NTf}_{2}\right]$ from 283.15 to $353.15 \mathrm{~K}$ at $p=0.1 \mathrm{MPa}$

\begin{tabular}{cccc}
\hline$T / \mathrm{K}$ & $\rho /\left(\mathrm{g} \cdot \mathrm{cm}^{-3}\right)$ & $\eta /(\mathrm{mPa} \cdot \mathrm{s})$ & $\sigma /\left(\mathrm{mS} \cdot \mathrm{cm}^{-1}\right)$ \\
\hline 283.15 & 1.2027 & 530.84 & 0.173 \\
288.15 & 1.1985 & 379.98 & 0.238 \\
293.15 & 1.1943 & 278.25 & 0.318 \\
298.15 & 1.1903 & 207.71 & 0.419 \\
303.15 & 1.1863 & 157.91 & 0.545 \\
308.15 & 1.1823 & 122.01 & 0.709 \\
313.15 & 1.1783 & 95.748 & 0.874 \\
318.15 & 1.1744 & 76.216 & 1.089 \\
323.15 & 1.1704 & 61.471 & 1.342 \\
328.15 & 1.1665 & 50.185 & 1.635 \\
333.15 & 1.1625 & 41.446 & 1.952 \\
338.15 & 1.1586 & 34.559 & 2.320 \\
343.15 & 1.1547 & 29.108 & 2.730 \\
348.15 & 1.1508 & 24.739 & 3.200 \\
353.15 & 1.1469 & 21.198 & 3.730 \\
\hline
\end{tabular}

The uncertainty is $\pm 0.0002 \mathrm{~g} \cdot \mathrm{cm}^{-3}$ for density.

The uncertainties are $\pm 1 \%$ for electrical conductivity and dynamic viscosity. The uncertainty is $\pm 0.05 \mathrm{~K}$ for temperature.

At $293.15 \mathrm{~K}$, the densities of [P4446][BF $]$ and [P4446][NTf $\left.{ }_{2}\right]$ are 1.0067 and $1.1943 \mathrm{~g} \cdot \mathrm{cm}^{-3}$, respectively. Although the value for $[\mathrm{P} 4446]\left[\mathrm{NTf}_{2}\right]$ is higher than $[\mathrm{P} 4446]\left[\mathrm{BF}_{4}\right]$, it is much lower than the common IL 1- butyl-3-methylimidazolium bis(trifluoromethylsulfonyl)imide $\left[\mathrm{C}_{4} \mathrm{mim}\right]\left[\mathrm{NTf}_{2}\right]\left(1.4378 \mathrm{~g} \cdot \mathrm{cm}^{-3}\right)^{32}$.

At $298.15 \mathrm{~K}$, the dynamic viscosity of the $[\mathrm{P} 4446]\left[\mathrm{BF}_{4}\right]$ and [P4446][NTf 2 are 1415.2 and $207.71 \mathrm{mPa} \cdot \mathrm{s}$, respectively. These values are much higher than for the ILs $\left[\mathrm{C}_{4} \mathrm{mim}\right]\left[\mathrm{BF}_{4}\right](75 \mathrm{mPa}$. s) and $\left[\mathrm{C}_{4} \mathrm{mim}\right]\left[\mathrm{NTf}_{2}\right](40 \mathrm{mPa} \cdot \mathrm{s})^{33}$. The electrical conductivities 
Table 4 Density, dynamic viscosity, and electrical conductivity of the some tetra-alkyl phosphonium type ionic liquids with literature at $298.15 \mathrm{~K}$

\begin{tabular}{|c|c|c|c|c|c|c|c|}
\hline \multirow{3}{*}{$\begin{array}{l}\text { Parameter } \\
\rho /\left(\mathrm{g} \cdot \mathrm{cm}^{-3}\right)\end{array}$} & \multicolumn{7}{|c|}{ Value } \\
\hline & \multicolumn{2}{|c|}{$[\mathrm{P} 4446]\left[\mathrm{BF}_{4}\right]$} & \multicolumn{2}{|c|}{$[\mathrm{P} 4448]\left[\mathrm{BF}_{4}\right]$} & \multicolumn{2}{|c|}{$[\mathrm{P} 444(12)]\left[\mathrm{BF}_{4}\right]$} & \\
\hline & \multicolumn{2}{|c|}{1.0036} & $0.9894^{\mathrm{e}}$ & $1.02^{\mathrm{b}}$ & $0.9670^{\mathrm{e}}$ & $0.97^{\mathrm{b}}$ & \\
\hline$\eta /(\mathrm{mPa} \cdot \mathrm{s})$ & \multicolumn{2}{|c|}{1415.2} & \multicolumn{2}{|c|}{$1240^{\mathrm{b}}$} & \multicolumn{2}{|c|}{$1310^{\mathrm{b}}$} & \\
\hline \multirow[t]{2}{*}{$\sigma /\left(\mathrm{mS} \cdot \mathrm{cm}^{-1}\right)$} & \multicolumn{2}{|c|}{0.0904} & \multicolumn{2}{|c|}{$0.069^{\mathrm{b}}$} & \multicolumn{2}{|c|}{$0.0468^{b}$} & \\
\hline & \multicolumn{2}{|c|}{$[\mathrm{P} 4446]\left[\mathrm{NTf}_{2}\right]$} & \multicolumn{2}{|c|}{$[\mathrm{P} 4448]\left[\mathrm{NTf}_{2}\right]$} & \multicolumn{2}{|c|}{$[\mathrm{P} 444(12)]\left[\mathrm{NTf}_{2}\right]$} & {$[\mathrm{P} 666(14)]\left[\mathrm{NTf}_{2}\right]$} \\
\hline$\rho /\left(\mathrm{g} \cdot \mathrm{cm}^{-3}\right)$ & 1.1903 & $1.18^{\mathrm{a}}$ & $1.1666^{\circ}$ & $1.18^{\mathrm{b}}$ & $1.1276^{\mathrm{e}}$ & $1.13^{\mathrm{b}}$ & $1.0654^{\circ}$ \\
\hline$\eta /(\mathrm{mPa} \cdot \mathrm{s})$ & 207.71 & $261^{\mathrm{a}}$ & \multicolumn{2}{|c|}{$250^{\mathrm{b}}$} & \multicolumn{2}{|c|}{$303^{\mathrm{b}}$} & $376.0^{d}$ \\
\hline$\sigma /\left(\mathrm{mS} \cdot \mathrm{cm}^{-1}\right)$ & 0.419 & $0.43^{\mathrm{a}}$ & \multicolumn{2}{|c|}{$0.268^{\mathrm{b}}$} & \multicolumn{2}{|c|}{$0.177^{\mathrm{b}}$} & \\
\hline
\end{tabular}

${ }^{\mathrm{a}}$ Ref.7, ${ }^{\mathrm{b}}$ Ref.6, ${ }^{\mathrm{c}}$ Ref.19, ${ }^{\mathrm{d}}$ Ref.22, ${ }^{\mathrm{e}}$ predicted value

of $[\mathrm{P} 4446]\left[\mathrm{BF}_{4}\right]$ and $[\mathrm{P} 4446]\left[\mathrm{NTf}_{2}\right]$ are 0.0904 and $0.419 \mathrm{mS} \cdot$ $\mathrm{cm}^{-1}$, respectively, and these values are much lower than those for ILs $\left[\mathrm{C}_{4} \mathrm{mim}\right]\left[\mathrm{BF}_{4}\right]\left(4.5 \mathrm{mS} \cdot \mathrm{cm}^{-1}\right)$ and $\left[\mathrm{C}_{4} \mathrm{mim}\right]\left[\mathrm{NTf}_{2}\right](4.6 \mathrm{mS} \cdot$ $\left.\mathrm{cm}^{-1}\right)^{33}$.

To compare the density, dynamic viscosity, and electrical conductivity of the tetra(alkyl)phosphonium type ionic liquids with reported literature values ${ }^{6,7,19,22}$, the above property values of the TAPILs determined at $298.15 \mathrm{~K}$ are listed in Table 4 . The TAPIL anions are $\left[\mathrm{BF}_{4}^{-}\right]$and $\left[\mathrm{NTf}_{2}^{-}\right]$.

From Table 3, the values at $298.15 \mathrm{~K}$ of density, dynamic viscosity, and electrical conductivity of [P4446] [ $\left.\mathrm{NTf}_{2}\right]$ are $1.1903 \mathrm{~g} \cdot \mathrm{cm}^{-3}, 207.71 \mathrm{mPa} \cdot \mathrm{s}$, and $0.419 \mathrm{mS} \cdot \mathrm{cm}^{-1}$, respectively. At the same temperature, the values of the reference are $1.18 \mathrm{~g} \cdot$ $\mathrm{cm}^{-3}, 261 \mathrm{mPa} \cdot \mathrm{s}$, and $0.43 \mathrm{mS} \cdot \mathrm{cm}^{-1}$, respectively ${ }^{7}$. From the literature ${ }^{7}$, the density, dynamic viscosity, and electrical conductivity values were measured by a precalibrated pycnometer, slow- flow viscometer, and ThermoOrion conductivity meter, respectively. The primary reasons for discrepancies with the literature values are the water content, instrumentation used, and purity of the [P4446][NTf 2 .

\subsection{Density}

The temperature dependence on the density can be plotted (see Fig.1) and fitted over the temperature range from $(283.15 \pm 0.05)$ to $(353.15 \pm 0.05) \mathrm{K}$ by the following equation:

$$
Y=A+B T
$$

where $Y$ is the density; and $A$ and $B$ are adjustable parameters. The fitting equations are obtained from $Y=1.1844-6.06 \times 10^{-4} \mathrm{~T}$ for $[\mathrm{P} 4446]\left[\mathrm{BF}_{4}\right]$ and $Y=1.4273-7.95 \times 10^{-4} T$ for $[\mathrm{P} 4446]\left[\mathrm{NTf}_{2}\right]$. The correlation coefficients of the two TAPILs are 0.9999 , which indicates that the linear equation represents the density very well.

The temperature dependence on $\ln \rho$ can be fitted by the following linear equation:

$$
\ln \rho=b-\alpha T
$$

where $b$ is an empirical constant and $\alpha$ is the thermal expansion coefficient. The fitting equations are $\ln \rho=0.1860-6.11 \times 10^{-4}$ $T$ for $[\mathrm{P} 4446]\left[\mathrm{BF}_{4}\right]$, and $\ln \rho=0.3760-6.77 \times 10^{-4} T$ for $[\mathrm{P} 4446]$ [NTf ${ }_{2}$. The correlation coefficients are higher than 0.9999 for both cases, thus indicating that the empirical linear equation represents the density very well. From Equation (2), the thermal expansion coefficients are $6.11 \times 10^{-4}$ for $\left[\mathrm{P}_{4} 446\right]\left[\mathrm{BF}_{4}\right]$ and $6.77 \times 10^{-4}$ for
$[\mathrm{P} 4446]\left[\mathrm{NTf}_{2}\right]$. These values are in good agreement with the values reported by Jacquemin et al..$^{34}$ that ranged between $5 \times 10^{-4}$ and $7 \times 10^{-4} \mathrm{~K}^{-1}$ (at $293.15 \mathrm{~K},[\mathrm{Bmim}]\left[\mathrm{NTf}_{2}\right]$ are $6.51 \times 10^{-4}$ and $6.90 \times 10^{-4} \mathrm{~K}^{-1}$ at dried and saturated, respectively; like: [Bmim] $\left[\mathrm{BF}_{4}\right]$ is $5.95 \times 10^{-4}$ at dried). The thermal expansion coefficients of the two TAPILs at $298.15 \mathrm{~K}$ are listed in Table 5.

At $298.15 \mathrm{~K}$, the molecular volume, $V_{\mathrm{m}}$, standard molar entropy, $S^{\circ}$, and lattice energy, $U_{\text {POT, }}$, were calculated for the TAPILs [P4446] $\left[\mathrm{BF}_{4}\right]$ and $[\mathrm{P} 4446]\left[\mathrm{NTf}_{2}\right]$ by the traditional empirical equations from the density ${ }^{32}$ :

$$
\begin{aligned}
& V_{\mathrm{m}}=M /(N \rho) \\
& S^{0}=1246.5 V_{\mathrm{m}}+29.5 \\
& U_{\text {POT }}=1981.2(\rho / M)^{1 / 3}+103.8
\end{aligned}
$$

where $M$ is the molar mass, $\rho$ is the density, and $N$ is Avogadro's constant. The obtained data from the above equations are listed in Table 5.

From Table 5, the lattice energy values are $379.0 \mathrm{~kJ} \cdot \mathrm{mol}^{-1}$ for $[\mathrm{P} 4446]\left[\mathrm{BF}_{4}\right]$ and $357.4 \mathrm{~kJ} \cdot \mathrm{mol}^{-1}$ for $[\mathrm{P} 4446]\left[\mathrm{NTf}_{2}\right]$. These values are much lower than for traditional organic melt salts. For example, the lowest lattice energy among the alkali halides is for fused CsI $\left(613 \mathrm{~kJ} \cdot \mathrm{mol}^{-1}\right)^{35}$. The lower lattice energy may be a reason why the two TAPILs have relatively low melting temperatures, such that $[\mathrm{P} 4446]\left[\mathrm{BF}_{4}\right]$ and $[\mathrm{P} 4446]\left[\mathrm{NTf}_{2}\right]$ can exist in the liquid state at room temperature.

From Table 5, the molecular volumes are $0.6195 \mathrm{~nm}^{3}$ for $[\mathrm{P} 4446]\left[\mathrm{BF}_{4}\right]$ and $0.7922 \mathrm{~nm}^{3}$ for $[\mathrm{P} 4446]\left[\mathrm{NTf}_{2}\right]$. These values

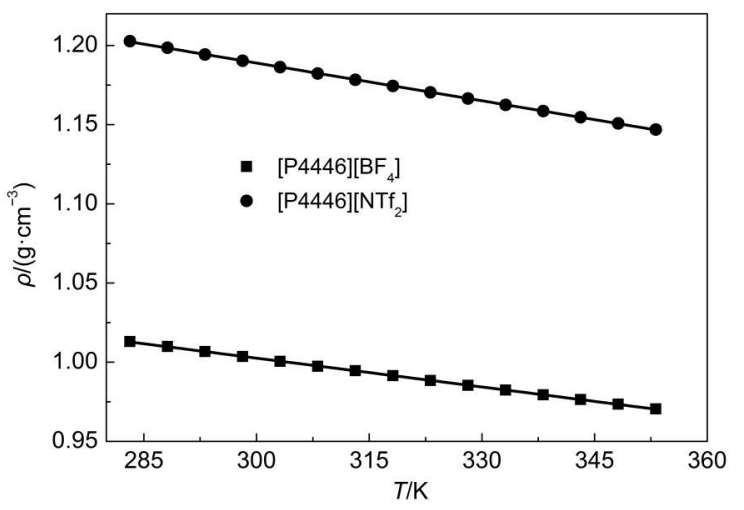

Fig.1 Plots of density vs temperature of two TAPILs [P4446][BF and [P4446][NTf $f_{2}$ from 283.15 to $353.15 \mathrm{~K}$ 
Table 5 Estimated values of physicochemical properties of two TAPILs [P4446][BF 4 and [P4446][NTf $\left.f_{2}\right]$ at $298.15 \mathrm{~K}$

\begin{tabular}{ccc}
\hline \multirow{2}{*}{ Parameter } & \multicolumn{2}{c}{ Value } \\
\cline { 2 - 3 } & {$[\mathrm{P} 4446]\left[\mathrm{BF}_{4}\right]$} & {$[\mathrm{P} 4446]\left[\mathrm{NTf}_{2}\right]$} \\
\hline$M /\left(\mathrm{g} \cdot \mathrm{mol}^{-1}\right)$ & 374.29 & 567.63 \\
$V_{\mathrm{m}} / \mathrm{nm}^{3}$ & 0.6195 & 0.7922 \\
$10^{4} \alpha / \mathrm{K}^{-1}$ & 6.11 & 6.77 \\
$V /\left(\mathrm{cm}^{-3} \cdot \mathrm{mol}^{-1}\right)$ & 372.9 & 476.9 \\
$S^{0} /\left(\mathrm{J} \cdot \mathrm{K}^{-1} \cdot \mathrm{mol}^{-1}\right)$ & 801.7 & 1016.9 \\
$U_{\text {pot }} /\left(\mathrm{kJ} \cdot \mathrm{mol}^{-1}\right)$ & 379.0 & 357.4 \\
\hline
\end{tabular}

$M$ : molar mass; $V_{\mathrm{m}}$ : molecular volume; $\alpha$ : thermal expansion coefficients; $V$ : molar volume; $S^{0}$ : standard molar entropy; $U_{\text {pot: }}$ lattice energy

are higher than for more common ILs, e.g., $0.5320 \mathrm{~nm}^{3}$ for $\left[\mathrm{C}_{6}\right.$ py $]\left[\mathrm{NTf}_{2}\right]^{31}, 0.5593 \mathrm{~nm}^{3}$ for $\left[\mathrm{C}_{6} 3 \mathrm{mpy}\right]\left[\mathrm{NTf}_{2}\right]^{36}, 0.5633 \mathrm{~nm}^{3}$ for $\left[\mathrm{C}_{6} 4 \mathrm{mpy}\right]\left[\mathrm{NTf}_{2}\right]^{36}, 0.5406 \mathrm{~nm}^{3}$ for $\left[\mathrm{C}_{6} \mathrm{Mim}\right]\left[\mathrm{NTf}_{2}\right]^{37}$, and $0.5608 \mathrm{~nm}^{3}$ for $\left[\mathrm{C}_{6} \mathrm{DMim}\right]\left[\mathrm{NTf}_{2}\right]^{37}$.

According to previous reports, the mean contributions of the methylene group to the molecular volume are $0.0277 \mathrm{~nm}^{3}$ for $\left[\mathrm{C}_{n} 3 \mathrm{mpy}\right]\left[\mathrm{NTf}_{2}\right]^{36,38}, 0.0289 \mathrm{~nm}^{3}$ for $\left[\mathrm{C}_{n} 4 \mathrm{mpy}\right]\left[\mathrm{NTf}_{2}\right]^{38,39}, 0.0280$ $\mathrm{nm}^{3}$ for $\left[\mathrm{C}_{n}\right.$ py $]\left[\mathrm{NTf}_{2}\right]^{31,40}, 0.0282 \mathrm{~nm}^{3}$ for $\left[\mathrm{C}_{n} \operatorname{mim}\right]\left[\mathrm{NTf}_{2}\right]^{32}, 0.0272$ $\mathrm{nm}^{3}$ for $\left[\mathrm{C}_{n} \mathrm{mim}\right]\left[\mathrm{BF}_{4}\right]^{32}$, and $0.0279 \mathrm{~nm}^{3}$ for amino acid ionic liquids $^{41-44}$. From the literature ${ }^{45}$, the basic properties of 1-alkyl-3methylimizazolium tris(pentafluoroethyl) trifluorophosphate have been predicted in terms of the estimated molecular volume. In this work, we also predicted the properties of the series of TAPILs based on literature ${ }^{45}$ methods. The mean value of the contribution can be calculated to be $0.0280 \mathrm{~nm}^{3}$. The density, standard entropy, and lattice energy were predicted according to Equations (3) - (5), and the values are listed in Table 6 .

From Tables 4 and 6 , the predicted density values are agreement with the literature ${ }^{6}$, except for TAPIL $[\mathrm{P} 4448]\left[\mathrm{BF}_{4}\right]$. The comparison, between the values predicted in this work versus the literature shows that the method employed herein is suitable for the prediction of TAPIL properties.

\subsection{Electrical conductivity}

The molar electrical conductivities of TAPIL $[\mathrm{P} 4446]\left[\mathrm{BF}_{4}\right]$ and $[\mathrm{P} 4446]\left[\mathrm{NTf}_{2}\right]$ were calculated by the following equation:

$$
\Lambda=\sigma M \rho^{-1}
$$

where $\Lambda$ is the molar conductivity, $\sigma$ is the electrical conductivity, $M$ is the molar mass and $\rho$ is the density. The values of the molar conductivity are listed in Table 7.

The electrical conductivity of the TAPILs $\left[\mathrm{P}_{4446}\right]\left[\mathrm{BF}_{4}\right]$ and $[\mathrm{P} 4446]\left[\mathrm{NTf}_{2}\right]$ as a function of temperature is plotted in Fig.2. From Fig.2, it can be observed that for each TAPIL the electrical conductivity decreases significantly with an increase in temperature.

Vogel-Fulcher-Tammann (VFT) equations are commonly used for the fitting of temperature dependence to electrical conductivity for ILs. Herein, the temperature dependence of the electrical conductivity for the two TAPILs [P4446] $\left[\mathrm{BF}_{4}\right]$ and [P4446][NTf were also fitted according to the following VFT equation:

$$
\sigma=\sigma_{0} \exp \left(-B /\left(T-T_{0}\right)\right)
$$

where $\sigma$ is the electrical conductivity; and $\sigma_{0}, B$, and $T_{0}$ are fitting parameters. The fitted parameters of $\sigma_{0}, B$, and $T_{0}$, and the corresponding correlation coefficient, $R$, are listed in Table 8. From Table 8 , as for other types of IL, the experimental electrical conductivity fits well aginst temperature by the VFT equation.

The Arrhenius equation is commonly used to fit the electrical conductivity against temperature. However, Vila et al. ${ }^{46}$ have shown differing results for ILs, where the electrical conductivity does not always follow Arrhenius behavior with changes in temperature.

The Arrhenius equation is:

$$
\sigma=\sigma_{\infty} \exp \left(-E_{\sigma} /\left(k_{\mathrm{B}} T\right)\right)
$$

Table 6 Predicted values of the thermodynamic properties of the some tetra-alkyl phosphonium type ionic liquids at $298.15 \mathrm{~K}$

\begin{tabular}{|c|c|c|c|c|c|}
\hline$T / \mathrm{K}$ & {$[\mathrm{P} 4446]\left[\mathrm{BF}_{4}\right]$} & {$[\mathrm{P} 4446]\left[\mathrm{NTf}_{2}\right]$} & $T / \mathrm{K}$ & {$[\mathrm{P} 4446]\left[\mathrm{BF}_{4}\right]$} & {$[\mathrm{P} 4446]\left[\mathrm{NTf}_{2}\right]$} \\
\hline 283.15 & 0.011 & 0.082 & 323.15 & 0.153 & 0.651 \\
\hline 288.15 & 0.016 & 0.113 & 328.15 & 0.197 & 0.796 \\
\hline 293.15 & 0.024 & 0.151 & 333.15 & 0.249 & 0.953 \\
\hline 298.15 & 0.034 & 0.200 & 338.15 & 0.316 & 1.137 \\
\hline 303.15 & 0.047 & 0.261 & 343.15 & 0.394 & 1.342 \\
\hline 308.15 & 0.064 & 0.340 & 348.15 & 0.486 & 1.579 \\
\hline 313.15 & 0.088 & 0.421 & 353.15 & 0.598 & 1.846 \\
\hline 318.15 & 0.117 & 0.526 & & & \\
\hline
\end{tabular}

\begin{tabular}{cccccc}
\hline Ionic liquid & $M /\left(\mathrm{g} \cdot \mathrm{mol}^{-1}\right)$ & $V_{\mathrm{m}} / \mathrm{nm}^{3}$ & $\rho /\left(\mathrm{g} \cdot \mathrm{cm}^{-3}\right)$ & $S^{\circ} /\left(\mathrm{J} \cdot \mathrm{K}^{-1} \cdot \mathrm{mol}^{-1}\right)$ & $U_{\mathrm{po}} /\left(\mathrm{kJ} \cdot \mathrm{mol}^{-1}\right)$ \\
\hline$[\mathrm{P} 4446]\left[\mathrm{BF}_{4}\right]$ & 374.29 & 0.6195 & 1.0036 & 801.7 & 379.0 \\
{$[\mathrm{P} 4448]\left[\mathrm{BF}_{4}\right]$} & 402.34 & 0.6755 & 0.9894 & 871.5 & 371.2 \\
{$[\mathrm{P} 444(12)]\left[\mathrm{BF}_{4}\right]$} & 458.45 & 0.7875 & 0.9670 & 1011.1 & 357.9 \\
{$[\mathrm{P} 4446]\left[\mathrm{NTf}_{2}\right]$} & 567.60 & 0.7922 & 1.1903 & 1016.9 & 357.4 \\
{$[\mathrm{P} 4448]\left[\mathrm{NTf}_{2}\right]$} & 595.68 & 0.8482 & 1.1666 & 1086.7 & 351.7 \\
{$[\mathrm{P} 444(12)]\left[\mathrm{NTf}_{2}\right]$} & 651.79 & 0.9602 & 1.1276 & 1226.3 & 341.6 \\
\hline
\end{tabular}

Table 7 Molar electrical conductivity, $\Lambda$, of two TAPILs $\left[\mathrm{P4446}_{[}\left[\mathrm{BF}_{4}\right]\right.$ and $[\mathrm{P4446}]\left[\mathrm{NTf}_{2}\right]$ at the temperature from 283.15 to $353.15 \mathrm{~K}$

1: molar conductivity. The uncertainty is $\pm 1 \%$ for molar electrical conductivity. The uncertainty is $\pm 0.05 \mathrm{~K}$ for temperature. 


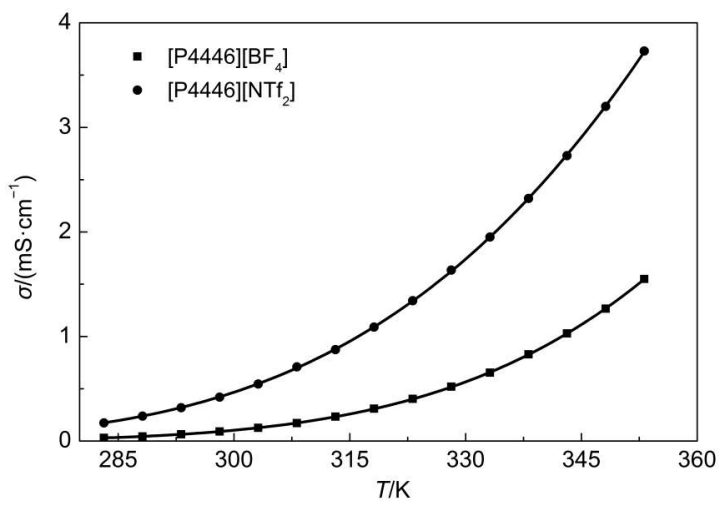

Fig.2 Plots of electrical conductivity $v$ s temperature of two TAPILs [P4446][BF 4 and [P4446][NTf ${ }_{2}$ from 283.15 to 353.15 K

$\ln \sigma=\ln \sigma_{\infty}-\left(E_{\sigma} / k_{\mathrm{B}}\right) T^{-1}$

where $E_{\sigma}$ is the activation energy, which indicates the energy needed for the ion to hop into a free hole, $\sigma_{\infty}$ is the maximum electrical conductivity and $k_{\mathrm{B}}$ is the Boltzmann constant. From Equation (9), a linear equation, the $1 / T$ dependence on $\ln \sigma$ was plotted for the two TAPILs [P4446] $\left[\mathrm{BF}_{4}\right]$ and $[\mathrm{P} 4446]\left[\mathrm{NTf}_{2}\right]$ (see Fig.3).

The plots should be on straight lines but the points clearly show that the experimental points are not on the straight lines (the solid straight lines were drawn to clarify the points). Therefore, the electrical conductivities of the TAPILs also do not follow Arrhenius behavior very well. Similar results were determined by us previously $^{36}$.

Vila et al. ${ }^{46}$ introduced the activation energy of the electrical conductivity into the VFT equation by establishing fitting parameters for the VFT equation via an Arrhenius equation: $\sigma_{0}=\sigma_{\infty}$ and $B=E_{\sigma} / k_{\mathrm{B}}$. The final version the VFT equation can therefore be expressed as follows:

$$
\sigma=\sigma_{\infty} \cdot \exp \left(-E_{\sigma} /\left(k_{\mathrm{B}}\left(T-T_{0}\right)\right)\right.
$$

The activation energies of electrical conductivities for TAPIL $[\mathrm{P} 4446]\left[\mathrm{BF}_{4}\right]$ and $[\mathrm{P} 4446]\left[\mathrm{NTf}_{2}\right]$ were calculated in this manner and are listed in Table 8.

\subsection{Dynamic viscosity}

The dynamic viscosities of the TAPILs $[\mathrm{P} 4446]\left[\mathrm{BF}_{4}\right]$ and [P4446][NTf 2$]$, as a function of temperature, are shown in Fig.4. From these values, it can be observed that the dynamic viscosity for each TAPIL decreases significantly with an increase in tem-

Table 8 Fitted parameter values of $\sigma_{0}, B, T_{0}$, and correlation coefficient, $R$, by equation (8) and activation enerty, $E_{\sigma}$, for

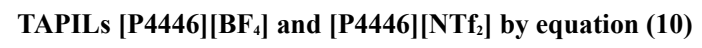

\begin{tabular}{ccc}
\hline Parameter & {$[\mathrm{P} 4446]\left[\mathrm{BF}_{4}\right]$} & {$[\mathrm{P} 4446]\left[\mathrm{NTf}_{2}\right]$} \\
\hline$\sigma_{0} /\left(\mathrm{S} \cdot \mathrm{cm}^{-1}\right)$ & 11.35 & 1.75 \\
$B / \mathrm{K}$ & 2026.5 & 1295.4 \\
$10^{3} E_{\sigma} / \mathrm{eV}$ & 174.9 & 111.8 \\
$T_{0} / \mathrm{K}$ & 125.5 & 142.6 \\
$R$ & 0.99998 & 0.99997 \\
\hline
\end{tabular}

$\sigma_{0}:$ the maximum electrical conductivity; $B$ : fitting parameters; $E_{\sigma}$ : activation energy; $T_{0}$ : fitting parameter; $R$ : correlation coefficient

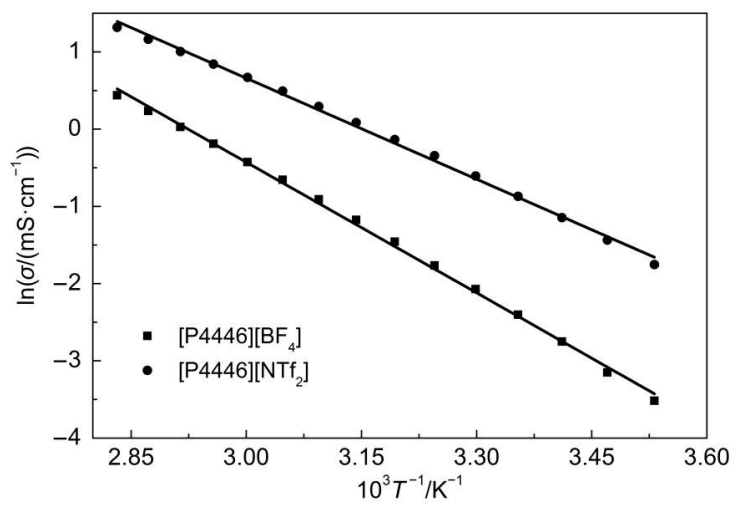

Fig.3 Plots of $\ln \sigma v s 1 / T$ of two TAPILs [P4446][BF 4 and [P4446][NTf $f_{2}$ from 283.15 to $353.15 \mathrm{~K}$

perature.

VFT equation is used for fitting the temperature dependence against the dynamic viscosity for ILs. Herein, the temperature dependence of the dynamic viscosity for each of the TAPILs $[\mathrm{P} 4446]\left[\mathrm{BF}_{4}\right]$ and $[\mathrm{P} 4446]\left[\mathrm{NTf}_{2}\right]$ were also fitted according to the following VFT equation:

$$
\eta=\eta_{0} \exp \left(B /\left(T-T_{0}\right)\right)
$$

where $\eta$ is the dynamic viscosity; and $\eta_{0}, B$, and $T_{0}$ are the fitting parameters. The best fitting parameters of $\eta_{0}, B, T_{0}$, and the corresponding correlation coefficient, $R$, are listed in Table 9. From Table 9, the obtained values of the correlation coefficient, $R$, are higher than 0.9999, which indicates that the VFT equation can be used for fitting the experimental dynamic viscosity.

As with the electrical conductivity, an Arrhenius equation was also used to fit the dynamic viscosity:

$$
\begin{aligned}
& \eta=\eta_{\infty} \exp \left(E_{\eta} /\left(k_{\mathrm{B}} T\right)\right) \\
& \ln \eta=\ln \eta_{\infty}+\left(E_{\eta} / k_{\mathrm{B}}\right) T^{-1}
\end{aligned}
$$

where $E_{\mathrm{a}}$ is the activation energy for the dynamic viscosity, $\eta_{\infty}$ is the maximum dynamic viscosity, and $k_{\mathrm{B}}$ is the Boltzmann constant. The $1 / T$ dependence of $\ln \eta$ was plotted for the TAPILs $[\mathrm{P} 4446]\left[\mathrm{BF}_{4}\right]$ and $[\mathrm{P} 4446]\left[\mathrm{NTf}_{2}\right]$ (see Fig.5). From Fig.5, as with the electrical conductivity shown above, the points are also not following the straight lines (The solid straight lines were drawn in order to clarify the points).

The activation energy of the dynamic viscosity was introduced

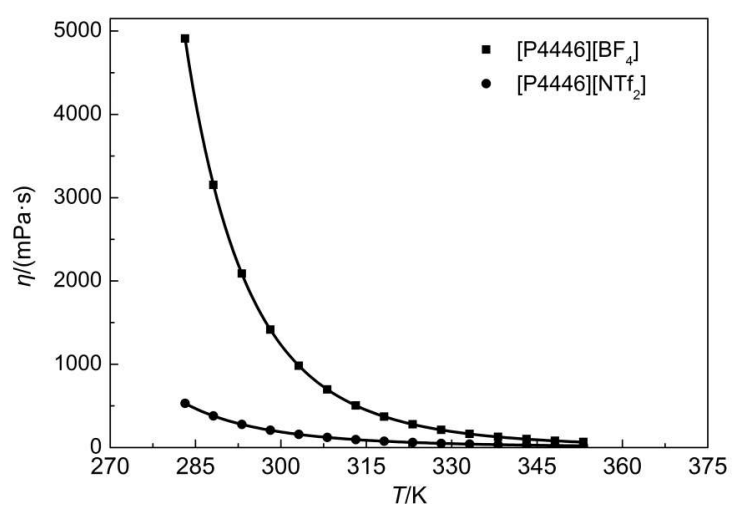

Fig.4 Plots of dynamic viscosity $v$ s temperature of two TAPILs $\left[\mathrm{P}_{4446}\right]\left[\mathrm{BF}_{4}\right]$ and $[\mathrm{P4446}]\left[\mathrm{NTf}_{2}\right]$ from 283.15 to $353.15 \mathrm{~K}$ 


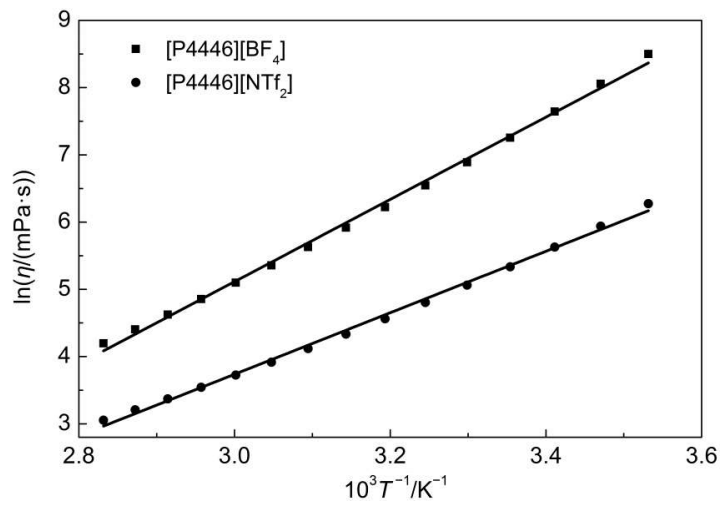

Fig.5 Plots of $\ln \eta$ vs $1 / T$ of two TAPILs [P4446][BF 4 and [P4446][NTf ${ }_{2}$ ] from 283.15 to $353.15 \mathrm{~K}$

into the VFT equation in a similar fashion as with the electrical conductivity above, and as discussed by Vila et al. ${ }^{46}$ The final version of the VFT equation can be expressed as:

$$
\eta=\eta_{\infty} \exp \left(E_{\eta} /\left(k_{\mathrm{B}}\left(T-T_{0}\right)\right)\right.
$$

The activation energies of the dynamic viscosity for the TAPILs $[\mathrm{P} 4446]\left[\mathrm{BF}_{4}\right]$ and $[\mathrm{P} 4446]\left[\mathrm{NTf}_{2}\right]$ were calculated and are listed in Table 9.

\subsection{Walden rule}

The relationship between the molar conductivity and dynamic viscosity for TAPILs [P4446] $\left[\mathrm{BF}_{4}\right]$ and $[\mathrm{P} 4446]\left[\mathrm{NTf}_{2}\right]$ can be described by Walden's rule $\mathrm{e}^{36,47-50}$ :

$$
\Lambda \eta=k
$$

where $\Lambda$ is the molar conductivity, $\eta$ is the dynamic viscosity, and $k$ is a temperature dependent constant. The Walden product at $298.15 \mathrm{~K}$ (in $\left.\left[\mathrm{S} \cdot \mathrm{cm}^{2} \cdot \mathrm{mol}^{-1}\right][\mathrm{mP} \cdot \mathrm{s}]\right)$ is 48 for $[\mathrm{P} 4446]\left[\mathrm{BF}_{4}\right]$ and 42 for $[\mathrm{P} 4446]\left[\mathrm{NTf}_{2}\right]$.

The $\lg \Lambda$ dependence on $\lg \eta^{-1}$ from 283.15 to $353.15 \mathrm{~K}$ is plotted in Fig.6 for the two TAPILs [P4446] $\left[\mathrm{BF}_{4}\right]$ and [P4446] $\left[\mathrm{NTf}_{2}\right]$. From Fig.6, the curves are approximately straight lines, which indicates that the ILs to some extent obey Walden's rule. The slopes of the lines for the TAPILs [P4446] $\left[\mathrm{BF}_{4}\right]$ and [P4446] $\left[\mathrm{NTf}_{2}\right]$ are 0.931 and 0.967 , respectively. These results indicate that the relationship between the conductivity and fluidity is a constant for both cases. The position of the ideal line was established by using aqueous $\mathrm{KCl}$ solutions at high dilution, and the lines for the two TAPILs are close to the ideal $\mathrm{KCl}$ line. Most of the previously reported ILs $\mathrm{I}^{36,47-50}$ show the same tendency. The TAPILs

Table 9 Fitted parameter values of $\eta_{0}, B, T_{0}$, and correlation coefficient, $R$, by equation (11) and activation energy, $E_{\eta}$, for

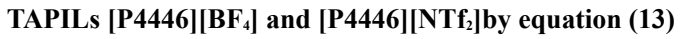

\begin{tabular}{ccc}
\hline Parameter & {$[\mathrm{P} 4446]\left[\mathrm{BF}_{4}\right]$} & {$[\mathrm{P} 4446]\left[\mathrm{NTf}_{2}\right]$} \\
\hline$\eta_{0} /(\mathrm{mPa} \cdot \mathrm{s})$ & 0.0085 & 0.0338 \\
$B / \mathrm{K}$ & 1922.3 & 1346.9 \\
$10^{3} E_{\eta} / \mathrm{eV}$ & 165.9 & 116.2 \\
$T_{0} / \mathrm{K}$ & 138.2 & 143.8 \\
$R$ & 0.99999 & 0.99999 \\
\hline
\end{tabular}

$\eta_{0}$ : the maximum dynamic viscosity; $B$ : fitting parameters; $E_{\eta}$ : activation energy; $T_{0}$ : fitting parameters; $R$ : correlation coefficient

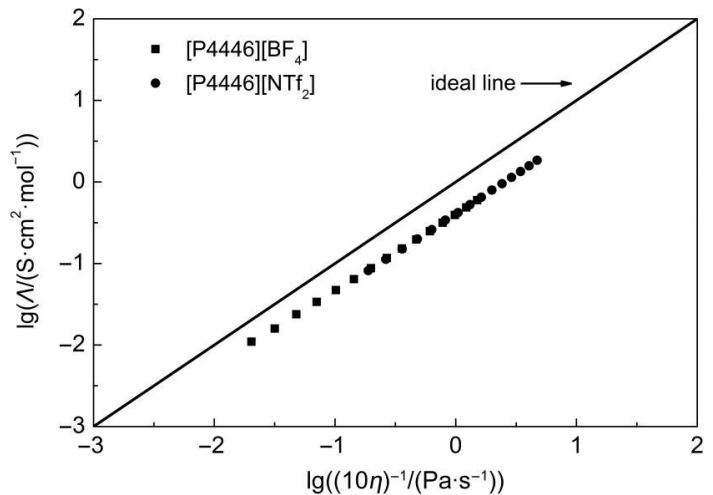

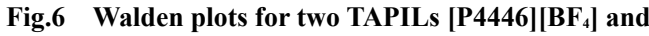
[P4446][NTf $\mathrm{P}_{2}$ ] from 283.15 to $353.15 \mathrm{~K}$

The solid straight line is the ideal line for aqueous $\mathrm{KCl}$ solutions at high dilution.

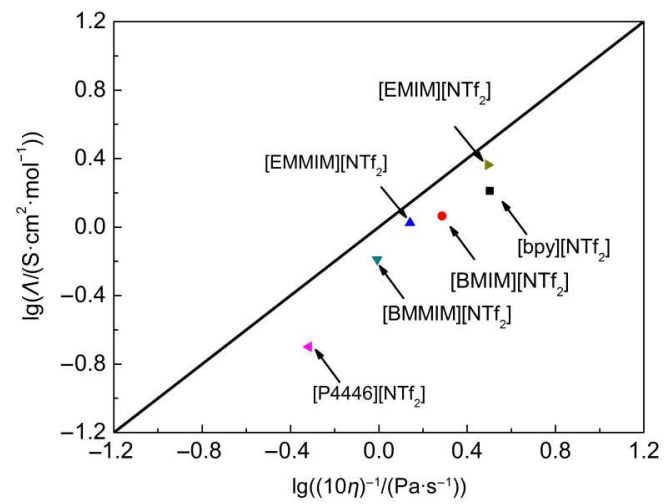

Fig.7 Walden plots for $[\mathrm{P4446}]\left[\mathrm{NTf}_{2}\right]$ and literature values at $298.15 \mathrm{~K}$

The solid straight line is the ideal line for aqueous $\mathrm{KCl}$ solutions at high dilution.

$[\mathrm{P} 4446]\left[\mathrm{BF}_{4}\right]$ and $[\mathrm{P} 4446]\left[\mathrm{NTf}_{2}\right]$ can be called "subionic"

To compare Walden plots, the values for [P4446] $\left[\mathrm{NTf}_{2}\right]$ and from previous literature ${ }^{40,52,53}$ are plotted in Fig.7.

\section{Conclusions}

The density, dynamic viscosity, and electrical conductivity of the air and water stable hydrophobic TAPILs [P4446] $\left[\mathrm{BF}_{4}\right]$ and $[\mathrm{P} 4446]\left[\mathrm{NTf}_{2}\right]$ were determined at atmospheric pressure over the temperature range from 283.15 to $353.15 \mathrm{~K}$. The experimental density and electrical conductivity values for anion $\left[\mathrm{NTf}_{2}\right]^{-}$are higher than for anion $\left[\mathrm{BF}_{4}\right]^{-}$. However, the dynamic viscosity shows the opposite trend, and the two TAPILs show very low densities. The thermal expansion coefficient, molecular volume, standard molar entropy, and lattice energy of the TAPILs were estimated by empirical equations. The two TAPILs show lower lattice energies than those of more traditional salts (e.g., CsI). The density and dynamic viscosity decrease, and the electrical conductivity increases, with an increase in temperature. The temperature dependence of the dynamic viscosity and electrical conductivity cannot be fitted by an Arrhenius equation (see Figs.3 and 5). However, the VFT equation can be used to fit the experimental values, and the TAPILs [P4446] $\left[\mathrm{BF}_{4}\right]$ and $[\mathrm{P} 4446]\left[\mathrm{NTf}_{2}\right]$ can be considered "subionic" according to Walden's rule. 
Supporting Information: The ${ }^{1} \mathrm{H}$ NMR spectra have been included. This information is available free of charge via the internet at http://www.whxb.pku.edu.cn.

\section{References}

(1) Rantwijk, F. V.; Sheldon, R. A. Chem. Rev. 2007, 107, 2757. doi: $10.1021 / \operatorname{cr} 050946 \mathrm{x}$

(2) Greaves, T. L.; Drummond, C. J. Chem. Rev. 2008, 108, 206. doi: $10.1021 / \mathrm{cr} 068040 \mathrm{u}$

(3) Hapiot, P.; Lagrost, C. Chem. Rev. 2008, 108, 2238. doi: 10.1021/cr0680686

(4) Jessop, P. G.; Subramaniam, B. Chem. Rev. 2007, 107, 2666. doi: $10.1021 / \mathrm{cr} 0401990$

(5) Tsunashima, K.; Sugiya, M. Electrochem. Commun. 2007, 9 , 2353. doi: 10.1016/j.elecom.2007.07.003

(6) Tsunashima, K.; Sugiya, M. Electrochemistry 2007, 75, 734. doi: 10.5796/electrochemistry.75.734

(7) Vega, J. A.; Zhou, J.; Kohl, P. A. J. Electrochem. Soc. 2009, 156, A253. doi: 10.1149/1.3070657

(8) Pomaville, R. M.; Poole, S. K.; Davis, L. J.; Poole, C. F. J. Chramatogr. 1988, 438, 1. doi: 10.1016/S0021-9673(00) 90227-9

(9) Breitbach, Z. S.; Armstrong, D. W. Anal. Bioanal. chem. 2008, 390, 1605. doi: 10.1007/s00216-008-1877-3

(10) Fukumoto, K.; Ohno, H. Angew. Chem. Int. Ed. 2007, 46, 1852. doi: 10.1002/anie.200604402

(11) Kohno, Y.; Deguchi, Y. Ohno, H. Chem. Commun. 2012, 48, 11883. doi: $10.1039 / \mathrm{c} 2 \mathrm{cc} 36913 \mathrm{c}$

(12) Kohno, Y.; Arai, H.; Saita, S.; Ohno, H. Aust. J. Chem. 2011, 64, 1560. doi: $10.1071 / \mathrm{CH} 11278$

(13) Kohno, Y.; Arai, H.; Ohno, H. Chem. Commun. 2011, 47, 4772. doi: 10.1039/C1CC10613A

(14) Wang, C.; Luo, X.; Luo, H.; Jiang, D.; Li, H.; Dai, S. Angew. Chem. Int. Ed. 2011, 50, 4918. doi: 10.1002/anie.201008151

(15) Wang, C.; Cui, G.; Luo, X.; Xu, Y.; Li, H.; Dai, S. J. Am. Chem. Soc. 2011, 133, 11916. doi: 10.1021/ja204808h

(16) Blundell, R. K.; Licence, P. Phys. Chem. Chem. Phys. 2014, 16, 15278. doi: 10.1039/C4CP01901F

(17) Chen, F. F.; Dong, Y.; Sang, X. Y.; Zhou, Y.; Tao, D. J. Acta Phys. -Chim. Sin. 2016, 32, 605. [陈凤凤, 董 艳, 桑晓燕, 周 言, 陶端健. 物理化学学报, 2016, 32, 605.] doi: 10.3866/PKU. WHXB201512241

(18) Ferreira, A. F.; Simões, P. N.; Ferreira, A. G. M. J. Chem. Thermodynamics 2012, 45, 16. doi: 10.1016/j.jct.2011.08.019

(19) Tariq, M.; Forte, P. A. S.; Gomes, M. F. C.; Lopes, J. N. C.; Rebelo, L. P. N. J. Chem. Thermodynamics 2009, 41, 790. doi: 10.1016/j.jct.2009.01.012

(20) Diogo, J. C. F.; Caetano, F. J. P.; Fareleira, J. M. N. A.; Wakeham, W. A. J. Chem. Eng. Data 2012, 57, 1015. doi: $10.1021 / \mathrm{je} 200830 \mathrm{j}$

(21) Goodrich, B. F.; Fuente, J. C. de la; Gurkan, B. E.; Lopez, Z. K.;
Price, E. A.; Huang, Y.; Brennecke, J. F. J. Phys. Chem. B 2011, 115, 9140. doi: 10.1021/jp2015534

(22) Baldo, M. A.; Oliveri, P.; Simonetti, R.; Daniele, S. J. Electroanal. Chem. 2014, 731, 43. doi: 10.1016/j. jelechem.2014.08.001

(23) Li, A.; Tian, Z.; Yan, T.; Jiang, D.; Dai, S. J. Phys. Chem. B 2014, 118, 14880. doi: 10.1021/jp5100236

(24) Tong, J.; Zhang, Q. G.; Hong, M.; Yang, J. Z. Acta Phys. -Chim. Sin. 2006, 22, 71. [佟 静, 张庆国, 洪 梅, 杨家振. 物理化学 学报, 2006, 22, 71.] doi: 10.3866/PKU.WHXB20060114

(25) Tong, J.; Chen, T. F.; Zhang, D.; Wang, L. F.; Tong, J.; Yang, J. Z. Acta Phys. -Chim. Sin. 2016, 32, 1161. [佟 静, 陈滕飞, 张 朵, 王林富, 佟 健, 杨家振. 物理化学学报, 2016, 32, 1161.] doi: 10.3866/PKU.WHXB201602232

(26) Bu, X. X.; Fan, B. H.; Wei, J.; Xing, N. N.; Ma, X. X.; Guan, W. Acta Phys. -Chim. Sin. 2016, 32, 267. [下晓雪, 謑本汉, 魏 杰, 邢楠楠, 马晓雪, 关 伟. 物理化学学报, 2016, 32, 267.] doi: 10.3866/PKU.WHXB201510303

(27) Hoogerstraete, T. V.; Binnemans, K. Green Chem. 2014, 16, 1594. doi: 10.1039/C3GC41577E

(28) Ferreira, C. E.; Talavera-Pieto, N. M. C.; Fonseca, I. M. A.; Portugal, A. T. G.; Ferreira, A. G. M. J. Chem. Thermodynamics 2012, 47, 183. doi: 10.1016/j.jct.2011.10.012

(29) Hayyan, M.; Mjalli, F. S.; Hashim, M. A.; AlNashef, I. M.; Tan, X. M.; Chooi, K. L. J. Appl. Sci. 2010, 10, 1176. doi: 10.3923/ jas.2010.1176.1180

(30) Tong, B.; Liu, Q. S.; Tan, Z. C.; Welz-Biermann, U. J. Phys. Chem. A 2010, 114, 3782. doi: 10.1021/jp9047538

(31) Liu, Q. S.; Yang, M.; Li, P. P.; Sun, S. S.; Welz-Biermann, U.; Tan, Z. C.; Zhang, Q. G. J. Chem. Eng. Data 2011, 56, 4094. doi: $10.1021 / \mathrm{je} 200534 \mathrm{~b}$

(32) Glasser, L. Thermochim. Acta 2004, 421, 87. doi: 10.1021/ je200830j

(33) McEwen, A. B.; Ngo, H. L.; LeCompte, K.; Goldman, J. L. J. Electrochem. Soc. 1999, 146, 1687. doi: 10.1149/1.1391827

(34) Jacquemin, J.; Husson, P.; Padua, A. A. H.; Majer, V. Green Chem. 2006, 8, 172. doi: 10.1039/B513231B

(35) Lide, D. R. Handbook of Chemistry and Physics, 82nd ed.; CRC Press: Boca Raton, FL, 2001-2002.

(36) Liu, Q. S.; Li, P. P.; Welz-Biermann, U.; Chen, J.; Liu, X. X. J. Chem. Thermodynamics 2013, 66, 88. doi: 10.1016/j. jct.2013.06.008

(37) Cheng, Z.; Lee, J. M. J. Phys. Chem. B 2014, 118, 2712. doi: $10.1021 / j p 411904 \mathrm{w}$

(38) Zhang, Q. G.; Wei, Y.; Sun, S. S.; Wang, C.; Yang, M.; Liu, Q. S.; Gao, Y. A. J. Chem. Eng. Data 2012, 57, 2185. doi: 10.1021/ je300153f

(39) Liu, Q. S.; Li, P. P.; Welz-Biermann, U.; Liu, X. X.; Chen, J. J. Chem. Eng. Data 2012, 57, 2999. doi: 10.1021/je3004645

(40) Liu, Q. S.; Yang, M.; Yan, P. F.; Liu, X. M.; Tan, Z. C.; WelzBiermann, U. J. Chem. Eng. Data 2010, 55, 4928. doi: 10.1021/ 
je100507n

(41) Fang, D. W.; Tong, J.; Guan, W.; Wang, H.; Yang, J. Z. J. Phys. Chem. B 2010, 114, 13808. doi: 10.1021/jp107452q

(42) Fang, D. W.; Guan, W.; Tong, J.; Wang, Z. W.; Yang, J. Z. J. Phys. Chem. B 2008, 112, 7499. doi: 10.1021/jp801269u

(43) Tong, J.; Song, B.; Wang, C. X.; Li, L.; Guan, W.; Fang, D. W.; Yang, J. Z. Ind. Eng. Chem. Res. 2011, 50, 2418. doi: 10.1021/ ie101903t

(44) Xu, W. G.; Ma, X. X.; Li, L.; Tong, J.; Guan, W. Ind. Eng. Chem. Res. 2012, 51, 4105. doi: 10.1021/ie201530b

(45) Liu, Q. S.; Tong, J.; Tan, Z. C.; Welz-Biermann, U.; Yang, J. Z. J. Chem. Eng. Data 2010, 55, 2586. doi: 10.1021/je901035d

(46) Vila, J.; Ginés, P.; Pico, J. M.; Franjo, C.; Jiménez, E.; Varela, L. M.; Cabeza, O. Fluid Phase Equilibria 2006, 242, 141. doi: 10.1016/j.uid.2006.01.022

(47) Yoshizawa, M.; Xu, W.; Angell, C. A. J. Am. Chem. Soc. 2003,
125, 15411. doi: 10.1021/ja035783d

(48) Angell, C. A.; Byrne, N.; Belieres, J. P. Acc. Chem. Res. 2007, 40, 1228. doi: $10.1021 /$ ar7001842

(49) Xu, W.; Cooper, E. I.; Angell, C. A. J. Phys. Chem. B 2003, 107, 6170. doi: $10.1021 / j p 0275894$

(50) MacFarlane, D. R.; Forsyth, M.; Izgorodina, E. I.; Abbott, A. P.; Annat, G.; Fraser, K. Phys. Chem. Chem. Phys. 2009, 11, 4962. doi: 10.1039/B900201D

(51) Belieres, J. P.; Angell, C. A. J. Phys. Chem. B 2007, 111, 4926. doi: 10.1021/jp067589u

(52) Cheng, Z.; Lee, J. M. J. Phys. Chem. B 2014, 118, 2712. doi: $10.1021 / \mathrm{jp} 411904 \mathrm{w}$

(53) Liu, Q. S.; Yan, P. F.; Yang, M.; Tan, Z. C.; Li, C. P.; WelzBiermann, U. Acta Phys. -Chim. Sin. 2011, 27, 2762. [刘青山, 颜佩芳, 杨 揫, 谭志诚, 李长平, Welz-Biermann, Urs. 物理化 学学报, 2011, 27, 2762.] doi: 10.3866/PKU.WHXB20112762 
Supporting Information for Acta Phys. -Chim. Sin. 2017, 33 (4), 736-744

doi: 10.3866/PKU.WHXB201612293

\title{
两种疏水型膦类离子液体的密度、动力粘度及电导率
}

\author{
郑其格 ${ }^{1}$ 刘 惠 ${ }^{2,3}$ 夏 泉 $^{1}$ 刘青山 ${ }^{1,4, *}$ 牟 林 $^{1, *}$ \\ ( ${ }^{1}$ 沈阳农业大学理学院, 沈阳 $110866{ }^{2}$ 上海环境卫生工程设计院, 上海 200232; \\ ${ }^{3}$ 上海污染场地修复工程技术研究中心, 上海 $200232 ;{ }^{4}$ 沈阳农业大学土地与环境学院, 沈阳 110866)
}

\section{Density, Dynamic Viscosity and Electrical Conductivity of Two Hydrophobic Phosphonium Ionic Liquids}

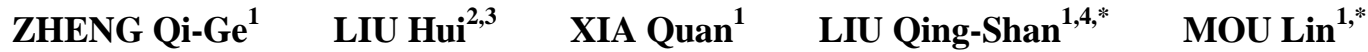 \\ $\left({ }^{1}\right.$ School of Science, Shenyang Agricultural University, Shenyang 110866, P. R. China; ${ }^{2}$ Shanghai Environmental \\ Sanitation Engineering Design Institute, Shanghai 200232, P. R. China; ${ }^{3}$ Shanghai Engineering Research Center \\ of Contaminated Sites Remediation, Shanghai 200232, P. R. China; ${ }^{4}$ College of Land and Environment, \\ Shenyang Agricultural University, Shenyang 110866, P. R. China)
}

${ }^{*}$ Corresponding authors. LIU Qing-Shan, Email: liuqingshan@dicp.ac.cn; Tel: +86-13478787524.

MOU Lin, Email: myname-mulin@tom.com; Tel: +86-13840537205. 


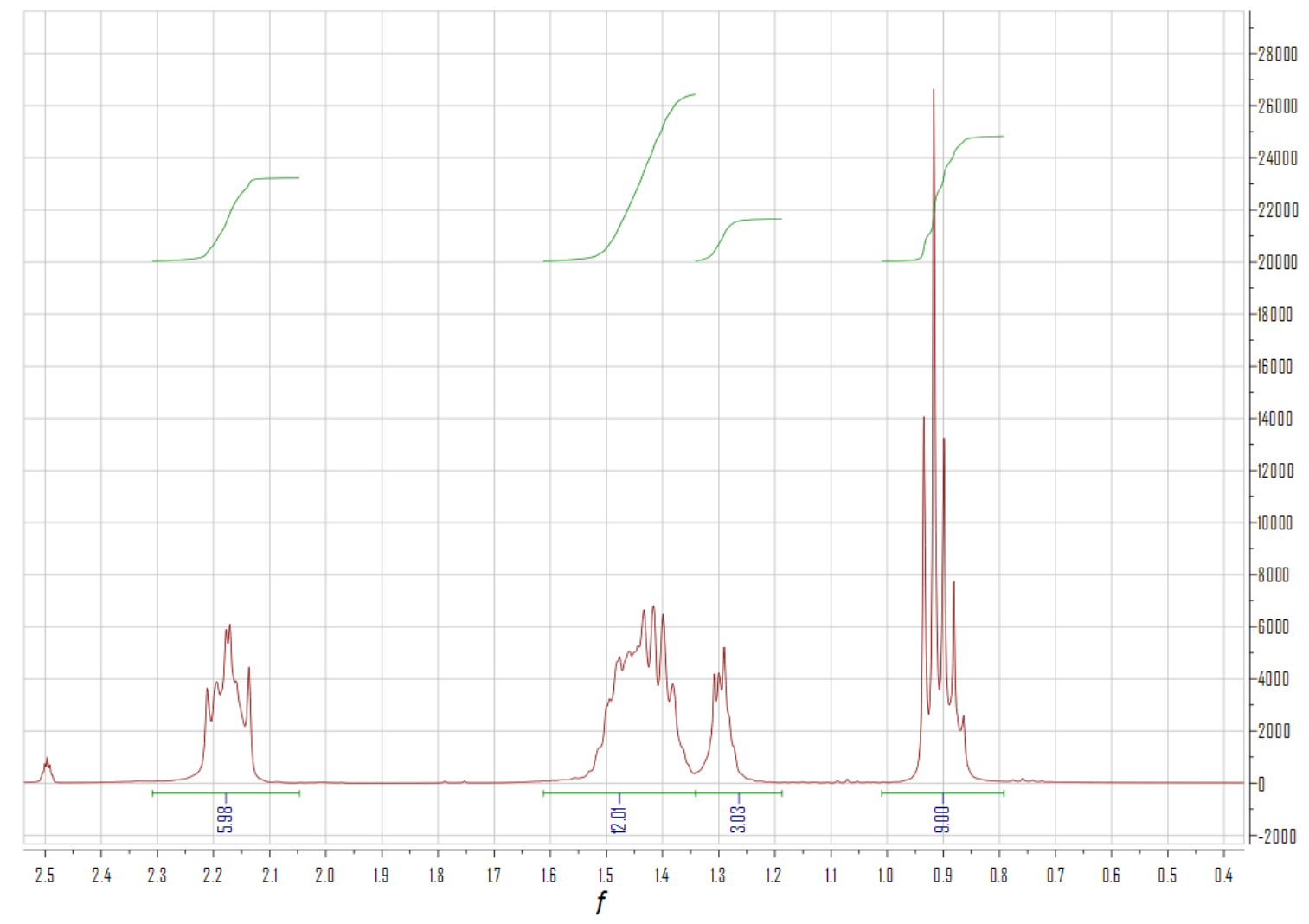

Fig.S1 ${ }^{1} \mathrm{H}$ NMR of $[\mathrm{P} 4446]\left[\mathrm{BF}_{4}\right]$

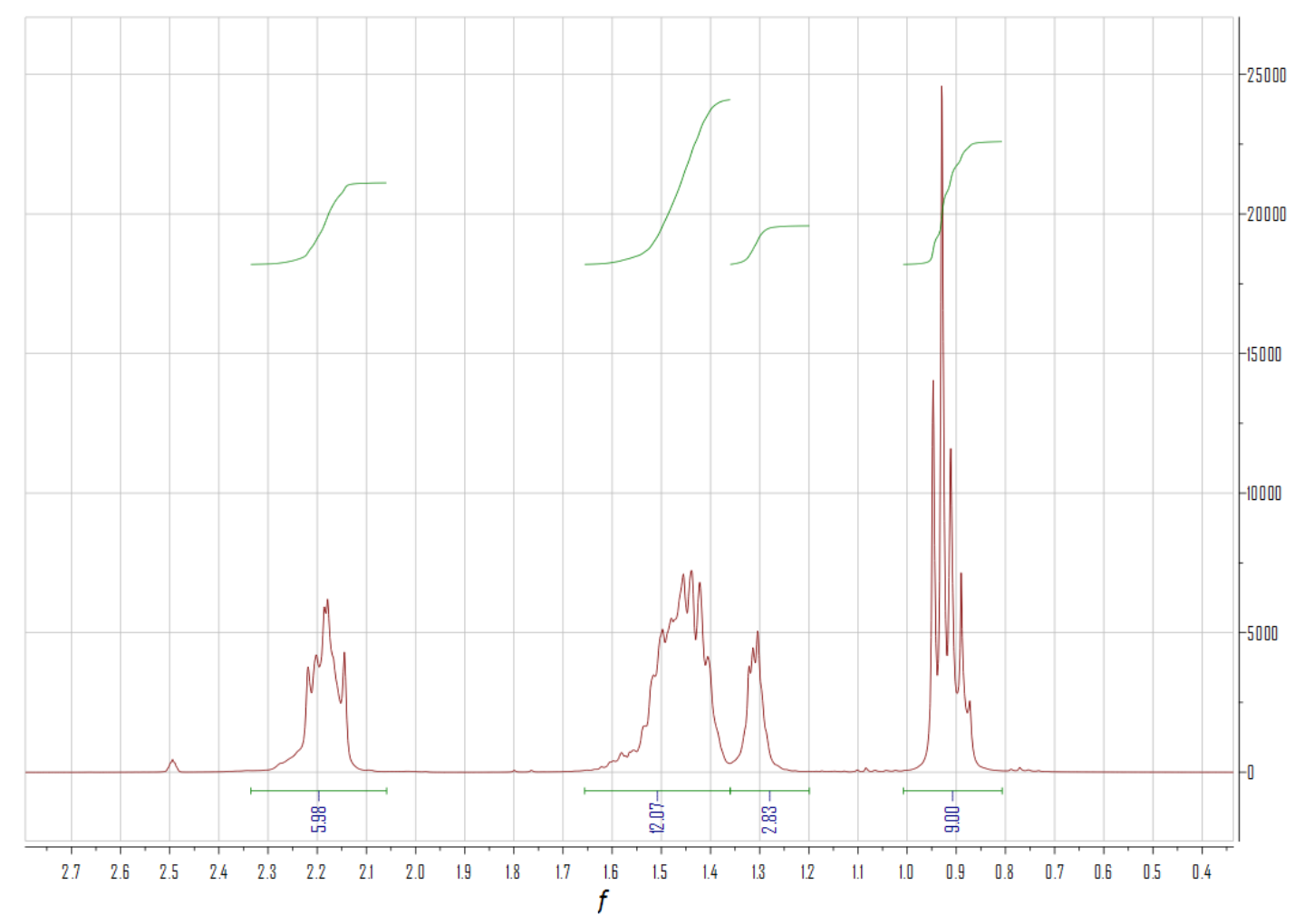

Fig.S2 ${ }^{1} \mathrm{H}$ NMR of $[\mathrm{P4446}]\left[\mathrm{NTf}_{2}\right]$ 